UDC 336.6

JEL: G30, G32

\author{
Andrii Ramskyi \\ D.Sc. (Economics), Professor, \\ Head of the Finance and Economics Department, \\ Borys Grinchenko Kyiv University, \\ Kyiv, Ukraine
}

ORCID ID: 0000-0001-7368-697X

e-mail:rama@ukr.net

Artem Solon'ko

Master of Science Degree

Boris Grinchenko Kyiv University,

Kyiv, Ukraine

ORCID ID:0000-0001-9776-3503

e-mail: ais.personality@gmail.com

\title{
MECHANISM OF FORMATION OF FINANCIAL SECURITY OF AN ENTERPRISE
}

\begin{abstract}
The article deals with the definition of financial security. Factors of the formation of its mechanism are identified. The objects and subjects of formation of the mechanism of financial security are shown and the principles and functions of the mechanism of financial security are disclosed. The research of existing theoretical approaches for determination of necessary conceptual apparatus is carried out. The analysis of the issue of the mechanism of formation of financial security of an enterprise and the review of the studies of domestic scientists and practitioners have been conducted. Also the analysis of the aspects of the definition of the structure of the category and the issue of structuring are defined. The role of financial security as a component of the economic security of an enterprise has been studied. The review of the methodical tools for evaluating financial component existing on the micro level has been considered. The category of financial security as a level of provision of enterprises with financial resources to meet their own needs and execute existing liabilities as well as the resistance to internal and external negative influences, characterized by the balance and their ability to provide financial stability, effective functioning and economic growth have been considered.

The economic content of the notion "mechanism of formation of financial security of an enterprise" is determined. "Financial and economic mechanism" as a combination of methods, and forms and a tool of exertion of influence on the economic and social stabilization of the enterprise through the state system support, which is founded on an institutional basis is considered. The analysis of the whole set of normative and legal acts, methods, measures, due to which the influence of the subject towards the objectfor creating security and countering threats is carried out. Investigated and taken into account are theoretical and practical processes of cyclic development of enterprises providing an opportunity for managers to make sound management decisions in the future. Models of behavior of the enterprise that determine its readiness for adaptation as well as models in the context of the company's life cycle are considered. Prospects for further research and issues that require consideration and development of real measures to counteract existing threats are highlighted.
\end{abstract}

Key words: financial security; formation of financial security; mechanism of financial security. 


\section{NTRODUCTION \\ Formulation of the problem. \\ Financial security is a major component} of the economic security of an enterprise, alongside with its other such components as personnel, technical and technological, intellectual, power, environmental, informational. One of the most important conditions for the successful growth and functioning of an enterprise is the formation of effective system of ensuring financial and economic security. In today's conditions effective management of the financial security system of an enterprise is carried out through mechanism of its economic management. Based on thisthe stability of work depends on the effectiveness of managing the financial security of economic entities and the mechanisms of its provision. The mechanism of financial security of an enterprise is a part of the mechanism of management and the mechanism of financial security management of an enterprise is a part of the system of provision of its financial security.

Analysis of recent research and publications. The problem of the mechanism of forming financial security of the enterprise attracted attention of a large number of domestic scientists, namely: T.G. Vasil'tsev, O.I. Karintsev, Yu.V. Lynnik, T.V. Klimenko, O.M. Lyashenko, I.P. Moiseenko, O.O. Shokol, O.V. Orlik, N. Poida-Nosik, V.V. Prokhorova.

Despite considerable interest of Ukrainian scholars and practitioners to the issues of the formation of the financial security mechanism, it should be noted that existing studies are mainly devoted to various aspects of determining the nature of the category and, to a much lesser extent, the question of structuring. Methodical tools of evaluating financial component existing on the micro level in general are studied only within the framework of economic security of the enterprise.

The purpose of the article is the research of theoretical and methodological foundations and principles of construction, definition of the functions and structure of the mechanism of the formation of financial security of the enterprise.

\section{RESULTS OF THE STUDY}

At present, the current economic situation is characterized by proliferation of destabilizing economic processes and conflict situations that are exerting profound influence on the activities of business entities. The assessment of scientific results of many scholars have shown that there is no undisputed definition of the concept of "financial security". For example, I. Baranovsky considers this category as a level of provision of enterprises with financial resources sufficient to meet their own needs and fulfil existing obligations as well as maintain the resistance to internal and external negative factors which is characterized by the balance and the ability to provide financial stability, effective functioning and economic growth [1].
According to M.M. Yermoshenko and K.S. Goryacheva, financial security is a state of financial safety characterized by the balance and quality of the financial set of tools that are used by the enterprise at its own discretion and also ensure the resistance to external and internal threats and the ability to provide sustainable and efficient development of the financial system of the enterprise [2].

Among the studies of foreign scientists, crucial is the approach of G. Shinazi, who defines financial security of enterprises as "the ability to promote and expand business processes of the corporation, manage risks of activities and level their consequences". So, based on this interpretation, the category of financial security is characterized by a feature of continuity in time: it can be modified only as a derivative set of all elements of the category of "finances" [3].

According to I. Blank's interpretation, financial security is a qualitatively and quantitatively determined level of the financial condition of the enterprise, which provides a stable protection of its balanced financial interests as opposed to potential and real threats of external and internal character, parameters of which are determined on the basis of financial philosophy and which create the necessary preconditions for financial support and its prospective growth in perspective and current periods [4].

A. Zagorodniy's vision of the economic essence of financial security is rather interesting. He regards it as the protection of financial interests of the subjects of management at all levels of financial relations as well as the provision of the enterprises, organizations and institutions with financial resources that are sufficient to meet their needs and execute their financial obligations [5].

In order to determine the content of the concept of "mechanism of the formation of financial security of the enterprise" let's conduct a study of existing theoretical approaches to determine necessary conceptual apparatus. It should be noted that the concept synthesizes in itself the notions of "mechanism" and "mechanism of formation". Despite different approaches of the scientists to determine the essence of the category of "mechanism", it is mostly investigated in economic, legal, market, financial contexts of macroeconomics. But in the economy of the enterprise, for the most part, the concept "financial and economic mechanism" is used.

Some scientists [6] consider this category as a set of methods and forms, tools and as the increasing impact on the economic and social stabilization of the enterprise through the system of state support, which is founded on the institutional basis. Instead, other researchers [7] believe that the mechanism expresses economic, legal, political and other management relationships, and its purpose is to create a system of conditions and relations of production, distribution, exchange and consumption 
(accumulation). That is, the "mechanism" is regarded as a set of methods, forms, tools, through which the impact on the activities of subjects of management based on the use of economic laws and categories to increase their efficiency is carried out.

Determining the economic content of "the mechanism of the formation of financial security of the enterprise", we note that in most scientific works the relevant category is identified with the notions of "mechanism of provision" and "management mechanism". In economic theory there exist several approaches to the definition of substantive essence of this economic term. The generalization of approaches makes it possible to state that, for the most part, it is defined as a set of tools, the use and control of which makes it possible to achieve a high level of economic security of the enterprise. Besides, it is a set of normative and legal acts, methods, measures through which the subject's impact on the object is realised to create security and counteract threats.

An approach that defines a complex administrative, insurance, legal, economic, security, regime and others means of protecting business from losses may be considered as an addition to this definition. The authors suggest a delineation of the concept "mechanism of provision" and "mechanism of formation". At the same time, in our opinion, "mechanism of formation" can be regarded as a way to exert the influence of the subject on the object by using various means, and the "mechanism of provision" is a set of measures for creation of reliable conditions for guaranteeing protection against threats.

Consequently, the mechanism of formation of financial security of the enterprise can be defined as a combination of the goal, targets, principles, methods, functions and tools that enable to diagnose, predict and control the state of economic security for adoption of adaptive solutions for the development of the enterprise. At the same time, in the structure of the mechanism the economic and security components of the organization, planning, and control to achieve the highest level of its security from internal and external threats should be combined .

Ensuring financial security of the enterprise determines the formation of necessary elements and general scheme of the organization. The analysis of scientific sources makes it possible to state that the elements of the mechanism can include the goal, measures, objects and subjects of management, functions, principles and methods of management, organizational structure, normative and legal support. The term "goal" implies the provision of security at the necessary level to achieve the company's tactical and strategic goals. The achievement of the goal is carried out by solving the main economic and organizational measures - such as planning of tasks, functions, principles of safety, the organization and formation of budget, financial security, control over compliance with planned indicators and analysis of deviations as well as diagnostics of the state of security.

The mechanism of the formation of financial security of the enterprise performs the following functions: the analysis of threats to the economic security of internal and external origin; formation and classification of economic interests of the enterprise; formation of the necessary resource potential for security; forecasting; planning (tactical and strategic) of production and economic activity of the enterprise; functional safety analysis; assessment of the status and diagnosis of the achieved level of safety. Among the existing structures, the most optimal in the context of the essence of the concept "Mechanism of the formation of financial security of the enterprise" is a model of the mechanism of management of economic development of the enterprise. Let's adapt the developed structure to the context of the formation of financial security of the enterprise, as a result of which we will define structural components of the mechanism (Fig. 1).

From the data given in (Fig. 1), it is evident that with its help the influence of management subjects (enterprise, management personnelor business process) is exerted on the object (economic relations affecting the level of economic security). The managerial staff of the enterprise sets goals, after considering which a system analyst formulates the tasks and criteria (quantitative analysis of goals) for functional managers, who, based on the principles of management, perform functions of planning, organization, stimulation, analysis and control. The authors also offers to synthesize in the structure of the general mechanism such local mechanisms as adaptation, diagnostics, identification of threats and assessment of the problems of formation of financial security.

In this case, the mechanism of adaptation which includes diagnostics of market environment, synthesis of adaptive models, adaptive decision making process and analysis of adaptive strategies is defined as crucial. In modern conditions of entrepreneurship the business structure in order to maintain competitive advantage must constantly adjust its own activity taking into account the requirements of the external environment, since the change of external factors can lead to imbalance between the enterprise and the environment [11]. In this regard, the company should be able to timely conduct adequate changes using adaptation methods. Being financially independent and completely responsible for the results of its activities, the enterprise in the market structure should form the system that would provide it with high efficiency, competitiveness and a stable market position. Moving to higher stages or, conversely, falling into crisis, businesses need to change goals, strategies and ways to implement them. Research and taking into account theoretical and practical prosseses of cyclical development of enterprises will enable managers to make sound management decisions in the future. An important task is the management of the financial security formation 
of the enterprise depending on the choice of an adaptive behavior model. The enterprise to succeed in business must constantly adapt to the requirements of the environment and in a timely manner respond to its changes. To do this you need to master, research and apply methods of adaptation of the enterprise. Scientists distinguish three patterns of behavior of enterprises, each of which defines their readiness for adaptation: active, conservative, mixed.

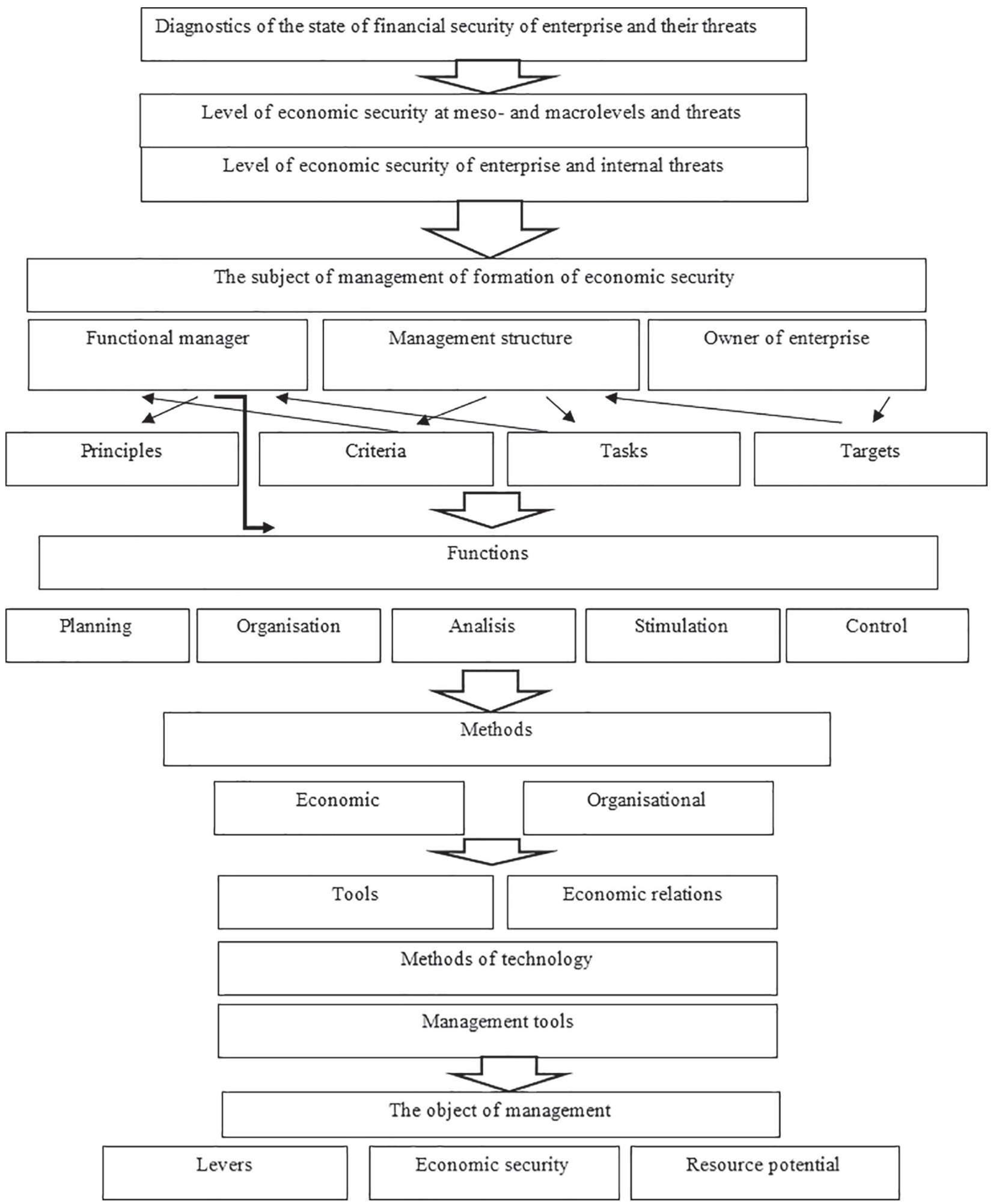

Fig.1. Structural components of the mechanism of the formation of financial security of the enterprise Source: Compiled by author's [11]

Considering the models in the context pricing approaches, searching for investment). of the enterprise life cycle, we note that an active In the conservative model the adaptive reaction has model of behavior is the adaptation of the enterprise a forced character (invariable structure of production, to market influences (establishing new connections, costly model of pricing), so the company must implement 
reorganization. For a mixed model of adaptation, typical is a combination of conservative and active behavior.

\section{CONCLUSIONS AND PERSPECTIVES FOR FURTHER STUDIES}

Thus, depending on the factors of influence, the whole set of adaptive measures of an enterprise should bedivided intogroups: adaptation toinnovations, to changes of market conditions, to he political and legal conditions. The process is complicated. It starts with complex diagnostics and may end with the reorganization of an enterprise structure. However, adaptation for many enterprises is not only a way out of a critical financial state, but also an important element of the mechanism of the formation of financial security through increased efficiency of the use of resources and preservation of market positions. The existence of a large number of threats requires the development and implementation of effective measures for providing financial security of the enterprise. The mechanism of its provision is an indispensable part of the system of economic security that is based on certain tasks, functions and principles and involves the use of its systemic set of methods, tools and concrete measures for their implementation of achieving the company's tactical and strategic goals.

\title{
REFERENCES
}

1. Baranovskyi O. (2013). Financial security. Kiev: Feniks. [in Ukrainian]

2. Yermoshenko N. (2016). Financial component of economic security: State and enterprise. Kiev: Natsionalna Akademiia Upravlinnia. [in Ukrainian]

3. Garry J. Schinasi. Defining Financial Stability / Schinasi Garry / / IMF Working Paper Series. — 2014. WP/04/187. - P. 1-16. [in English]

4. Blank I. (2014). Enterprise Financial Security Management . Kiev: Elha; Nyka-Tsentr. [in Russian]

5. Bondarchuk N. (2018). Management of the financial security system of the enterprise. Molodyi Vchenyi,9(61), 237-241. Retrieved November 27, 2018. [in Ukrainian]

6. Orlyk O. (2014). Economic security of an enterprise: Properties, strategy and methods of providing(Vol. 2). Dnipropetrovsk: FOP Drobiazko S.I. [in Ukrainian]

7. Vasyltsiv T., Voloshyn V., \& Boikevych O. (2012). Financial and economic security of Ukrainian enterprises: Strategy and mechanisms of provision. Lviv: Liha-Pres. [in Ukrainian]

8. Moiseienko I., \& Sholok O. (2013). Mechanism of management of financial and economic security of the enterprise. Naukovyi Visnyk NLTU Ukrainy,21(2), 141-146. Retrieved November 13, 2018. [in Ukrainian]

9. Poida-Nosyk N. (2015). Determination of the essence of the mechanism for ensuring financial security of business entities. Ternopil: Ternopilskyi Instytut Ahropromyslovoho Vyrobnytstva NAAN Ukrainy. Retrieved October 13, 2018, from http://conftiapv.at.ua/publ/konf_zhovtnja_2015_r/sekcija_5_ekonomichn_nauki/viznach ennja_sutnosti_mekhanizmu_zabezpechen nja_finansovoji_bezpeki_sub_ektiv_pidprie mnictva/. [in Ukrainian]

10. Prokhorova V. (2013). Economic development of enterprises: theoretical and methodological approach. Kharkiv. [in Ukrainian]

11. Klymenko T. (2013). The main elements of the mechanism of financial security of economic entities. Visnyk ZhDTU. Seriia Ekonomichni Nauky, 4 (58), 340-343. Retrieved November 13, 2018. [in Ukrainian]

\section{МЕХАНІЗМ ФОРМУВАННЯ ФІНАНСОВОÏ БЕЗПЕКИ ПІДПРИЄМСТВА}

\author{
Рамський Андрій Юрійович \\ Доктор економічних наук, дочент, \\ завідувач кафедри фінансів та економіки, \\ Київський університет імені Бориса Грінченка, \\ м. Київ, Україна \\ ORCID ID: 0000-0001-7368-697X \\ e-mail: rama@ukr.net \\ Солонько Артем Ігорович \\ Здобувач ступеня магістр, \\ Київський університет імені Бориса Грінченка \\ м. Київ, Україна \\ ORCID ID: 0000-0001-9776-3503 \\ e-mail: ais.personality@gmail.com
}

Анотація. В сmammi розглянуто визначення фінансової безпеки, визначені фрактори формування механізму фінансової безпеки, розкриті об'єкти та суб'єкти формування механізму 
фінансової безпеки, розкриті принципи та функції механізму фінансової безпеки, проведено дослідження існуючих теоретичних підходів для визначення необхідного понятійного anapamy, проведено аналіз питання механізму формування фінансової безпеки підприємства, розробок вітчизняних учених і практиків, проведено аналіз аспектів визначення структури категорії та питання структурування, визначено роль фінансової безпеки як складової економічної безпеки підприємства, проведено аналіз існуючого на мікрорівні методичного інструментарія оцінювання фінансової складової, розглянуто категорію фінансова безпеку як рівень забезпеченості підприємства фінансовими ресурсами, для задоволення власних потреб та виконання наявних зобов'язань, також стійкістю до внутрішніх та зовнішніх негативних впливів, що характеризуються збалансованістю та здатні забезпечити фінансову стійкість, та ефективне функціонування, та економічне зростання. Визначено економічний зміст "механізму формування фінансової безпеки підприємства», розглянуто «фінансово-економічний механізм» як сукупність методів і форм, інструментів і піднесення впливу на економічну й соціальну стабілізацію підприємства через систему державної підтримки, яка заснована на інституціональній базі. Проведено аналіз сукупності нормативно-правових актів, методів, заходів, завдяки яким відбувається вплив суб'єкта на об'єкт для створення безпеки та протидії загрозам. Досліджено та врахувано теоретичні і практичні прочеси циклічності розвитку підприємств, що дають можливість керівникам приймати обгрунтовані управлінські рішення в майбутньому. Розглянуто моделі поведінки підприємства які визначають його готовність до адаптації та моделі в контексті життєвого циклу підприємства. Виділено перспективи подальших досліджень, питання, що вимагають розглянення та розробки реальних заходів з протидії існуючим загрозам.

Ключові слова: фінансова безпека; формування фінансової безпеки; механізм фінансової безпеки.

\title{
МЕХАНИЗМ ФОРМИРОВАНИЯ ФИНАНСОВОЙ БЕЗОПАСНОСТИ ПРЕДПРИЯТИЯ
}

\section{Рамский Андрей Юрьевич}

Доктор экономических наук, дочент, заведующий кафедрой финансов и экономики, Киевский университет имени Бориса Гринченка, 2. Киев, Украина ORCID ID: 0000-0001-7368-697X

e-mail:rama@ukr.net

\section{Солонько Артем Игоревич}

Соискатель степени магистр,

Киевский университет имени Бориса Гринченка, 2. Киев, Украина ORCID ID: 0000-0001-9776-3503

e-mail: ais.personality@gmail.com

\begin{abstract}
Анотация. В статье рассмотрено определение финансовой безопасности, определенные факторы формирования механизма финансовой безопасности, раскрыты объекты и субъекты формирования механизма финансовой безопасности, раскрыты принципы и функции механизма финансовой безопасности, проведено исследование существующих теоретических подходов для определения необходимого понятийного аппарата, проведен анализ механизма формирование финансовой безопасности предприятия, научных разработок отечественных ученых и практиков, проведен анализ аспектов определения структуры категории и вопросы структурирования, определена роль финансовой безопасности как составляющей экономической безопасности предприятия, проведен анализ существующего на микроуровне методического инструментария оценки финансовой, рассмотрены категорию финансовая безопасность как уровень обеспеченности предприятия финансовыми ресурсами для удовлетворения собственных потребностей и выполнения имеющихся обязательств, также устойчивостью к внутренним и внешним негативным воздействий, характеризующихся сбалансированностью и способны обеспечить финансовую устойчивость и эффективное функционирование, и экономическое роста.
\end{abstract}


Oпределены экономическое содержание «механизма формирования финансовой безопасности предприятия», рассмотрены «финансово-экономический механизм» как совокупность методов и форм, инструментов и подъем влияния на экономическую и социальную стабилизацию предприятия через систему государственной поддержки, которая основана на институциональной основе. Проведен анализ совокупности нормативно-правовых актов, методов, мероприятий, благодаря которым происходит воздействие субъекта на объект для создания безопасности и противодействия угрозам.

Исследованы и учетены теоретические и практические процессы цикличности развития предприятий, дают возможность руководителям принимать обоснованные управленческие решения в будущем. Рассмотрены модели поведения предприятия которые определяют его готовность к адаптации и модели в контексте жизненного цикла предприятия. Выделены перспективы дальнейших исследований, вопросы, требующие розглянення и разработки реальных мер по противодействию существующим угрозам.

Ключевые слова: финансовая безопасность; формирование финансовой безопасности; механизм финансовой безопасности. 